\title{
EVALUATION OF POTENTIAL HYDROCARBON TRANSPORT AT THE UC-4 EMPLACEMENT HOLE, CENTRAL NEVADA TEST AREA
}

\author{
prepared by \\ Brad F. Lyles, Greg Pohll, Derek Sloop, Charalambos Papelis
}

submitted to

Nevada Operations Office

U.S. Department of Energy

September 1998 
This report was prepared as an account of work sponsored by the United States Government. Neither the United States nor the United States Department of Energy, nor any of their employees, nor any of their contractors, subcontractors or their employees, makes any warranty, express or implied, or assumes any legal liability or responsibility for the accuracy, completeness, or any third party's use or the results of such use of any information, apparatus, product, or process disclosed, or represents that its use would not infringe privately owned rights. Reference herein to any specific commercial product, process, or service by trade name, trademark, manufacturer, or otherwise, does not necessarily constitute or imply its endorsement, recommendation, or favoring by the United States Government or any agency thereof or its contractors or subcontractors. The views and opinions of authors expressed herein do not necessarily state or reflect those of the United States Government or any agency thereof.

This report has been reproduced directly from the best available copy.

Available to the public from:

U.S. Department of Commerce

National Technical Information Service

5285 Port Royal Rd.

Springfield, VA 22161

(703) $487-4650$

Available electronically at $h t t p: / / w w w . d o e . g o v / b r i d g e$

Available to the U.S. Department of Energy and its contractors from:

U.S. Department of Energy

Office of Scientific and Technical Information

P.O. Box 62

Oak Ridge, TN 37831

(423) 576-8401 


\title{
EVALUATION OF POTENTIAL HYDROCARBON TRANSPORT AT THE UC-4 EMPLACEMENT HOLE, CENTRAL NEVADA TEST AREA
}

\author{
prepared by \\ Brad F. Lyles, Greg Pohll, Derek Sloop, Charalambos Papelis \\ Water Resources Center \\ Desert Research Institute \\ University and Community College System of Nevada
}

Publication No. 45167

submitted to

Nevada Operations Office

U.S. Department of Energy

Las Vegas, Nevada

September 1998

The work upon which this report is based was supported by the U.S. Department of Energy under Contract \#DE-AC08-95NV11508. Approved for public release; further dissemination unlimited. 


\begin{abstract}
Emplacement hole UC-4 was drilled in 1969 at the Central Nevada Test Area and left filled with drilling mud. Surface characterization samples collected from abandoned mud pits in the area yielded elevated concentrations of total petroleum hydrocarbon, thereby raising a concern that the mud-filled emplacement hole may be leaching hydrocarbons into alluvial aquifers. This study was initiated to address this concern.

An analytical solution for flow near a wellbore was used to calculate the amount of time it would take for a contaminant to move through the mud-filled well and into the surrounding aquifer. No hydraulic data are available from the emplacement hole; therefore, ranges of hydraulic conductivity and porosity were used in 100 Monte Carlo realizations to estimate a median travel time. Laboratory experiments were performed on samples collected from the central mud pit to determine the hydrocarbon release function for the bentonite drilling mud.

The median contaminant breakthrough took about 12,000 years to travel $10 \mathrm{~m}$, while the initial breakthrough took about 300 years and the final breakthrough took about 33,000 years. At a distance of about $10 \mathrm{~m}$ away from the emplacement hole, transport velocity is dominated by the hydraulics of the aquifer and not by the emplacement hole hydraulics. It would take an additional 45,500 years for the contaminant to travel $800 \mathrm{~m}$ to the U.S. Department of Energy land exclusion boundary. Travel times were primarily affected by the hydraulic conductivity and porosity of the drilling mud, then by the hydraulic conductivity, porosity and hydraulic gradient of the alluvial aquifer, followed by the hydrocarbon release function.
\end{abstract}




\section{CONTENTS}

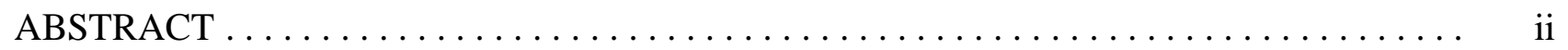

LIST OF FIGURES $\ldots \ldots \ldots \ldots \ldots \ldots \ldots \ldots \ldots \ldots \ldots \ldots \ldots \ldots \ldots \ldots \ldots$

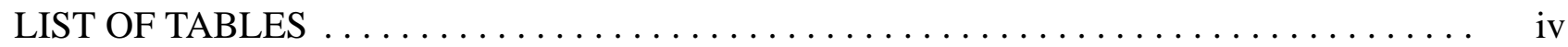

ACRONYMS $\ldots \ldots \ldots \ldots \ldots \ldots \ldots \ldots \ldots \ldots \ldots \ldots \ldots \ldots \ldots \ldots \ldots \ldots \ldots$

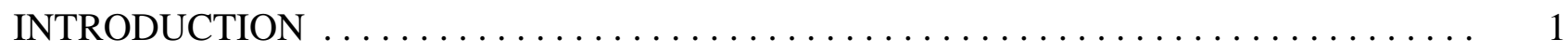

UC-4 DRILLING AND CHARACTERIZATION HISTORY $\ldots \ldots \ldots \ldots \ldots \ldots \ldots \ldots$

ANALYTICAL SOLUTION FOR FLOW NEAR A WELL OF

LOW HYDRAULIC CONDUCTIVITY $\ldots \ldots \ldots \ldots \ldots \ldots \ldots \ldots \ldots \ldots \ldots \ldots \ldots \ldots \ldots$

HYDROCARBON RELEASE FUNCTION $\ldots \ldots \ldots \ldots \ldots \ldots \ldots \ldots \ldots \ldots \ldots \ldots \ldots$

Laboratory Results and Discussion $\ldots \ldots \ldots \ldots \ldots \ldots \ldots \ldots \ldots \ldots \ldots \ldots \ldots \ldots \ldots \ldots \ldots$

COMPUTER MODEL DESIGN AND RESULTS $\ldots \ldots \ldots \ldots \ldots \ldots \ldots \ldots \ldots \ldots \ldots$

CONCLUSIONS $\ldots \ldots \ldots \ldots \ldots \ldots \ldots \ldots \ldots \ldots \ldots \ldots \ldots \ldots \ldots \ldots \ldots \ldots$

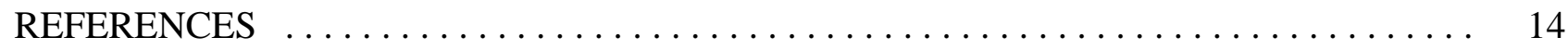

APPENDIX: TPH EXPERIMENTAL RESULTS $\ldots \ldots \ldots \ldots \ldots \ldots \ldots \ldots \ldots \ldots \ldots \ldots$ 


\section{FIGURES}

1. Location of well UC-4 at the Central Nevada Test Area in

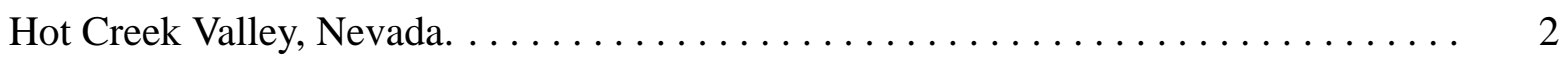

2. Generalized well schematic and lithologic $\log$ for well UC-4. . . . . . . . . 3

3. Flow lines of equal potential within $10 \mathrm{~m}$ of well UC-4. $\ldots \ldots \ldots \ldots \ldots$

4. Geometry of analytic solution. . $\ldots \ldots \ldots \ldots \ldots \ldots \ldots \ldots \ldots \ldots \ldots \ldots \ldots$

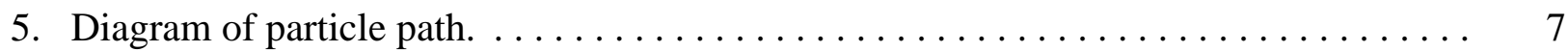

6. GC/FID chromatogram of the 35-day equilibrium TPH concentration of sample 1-1b. . 10

7. Cumulative normalized mass breakthrough of total petroleum hydrocarbon $10 \mathrm{~m}$ from

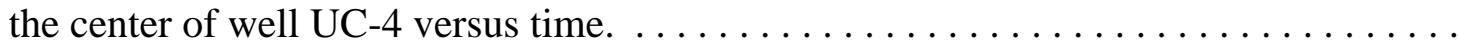

\section{TABLES}

1. A Summary of the Physical Characteristics of the Bentonite Drilling Mud Samples from the Central Mud Pit. . . . . . . . . . . . . . . . . . . . . . . . . . .

2. First-Order Rate Constants for the Dissolution of TPH from Bentonite Drilling Mud. . 


\section{ACRONYMS}

CNTA

DOE

EPA

FID

GC

HPLC

I.D.

IT

TPH

USAEC

VOA
Central Nevada Test Area

U.S. Department of Energy

U.S. Environmental Protection Agency

flame ionization detector

gas chromatograph

high pressure liquid chromatography

inside diameter

International Technology Corporation

total petroleum hydrocarbon

U.S. Atomic Energy Commission

volatile organic analysis 


\section{INTRODUCTION}

Calculations were performed to determine the nature and extent of potential groundwater contamination at well UC-4 on the Central Nevada Test Area (CNTA). Although the hydrocarbon concentration in the mud-filled borehole of UC-4 is unknown, as a conservative estimate, the highest observed concentrations of total petroleum hydrocarbon (TPH) from abandoned mud pits in the area were used. Laboratory experiments were performed to derive a release function for TPH from semi-consolidated mud samples collected from the central mud pit, near the UC-1 site. The source of TPH in the mud pit is not clear, but may be from one or more of the following sources: 1) used motor oil, 2) oil and grease from an equipment cleaning area near the mud pit, or 3) a drilling mud additive. TPH samples collected from the UC-4 mud pits had considerably lower concentration than from the central mud pit; however, as a worst-case scenario it was assumed that the same practices used at the central mud pit were used at the UC-4 mud pits. An analytic solution for groundwater flow near a borehole was used to estimate the transport of TPH. An exponential release function was used to simulate the TPH release from the drilling mud.

\section{UC-4 DRILLING AND CHARACTERIZATION HISTORY}

Emplacement hole UC-4 was drilled in the northernmost testing area of the CNTA (Figure 1). The exclusion area around the UC-4 site encompasses $3.88 \mathrm{~km}^{2}$ (Public Land Order No. 4748 of 12/2/1969). UC-4 was drilled from April to September 1969, to a total depth of $1676 \mathrm{~m}$ and is $3 \mathrm{~m}$ in diameter (see Figure 2). The upper $126.5 \mathrm{~m}$ of the hole was completed with 3.1-m-diameter steel casing, the remainder of the well was left uncased. Portions of bit \#45 were lost in the well on April 12, at a depth of $1407.2 \mathrm{~m}$. Fishing and milling operations lasted for the next 30 days (Fenix and Sisson, 1968). Although no details were recorded in the hole history regarding the addition of fluids during the fishing operation, it was not uncommon to inject large quantities of diesel fuel into the borehole during fishing operations as a lubricating agent (J.D. Donithan, Desert Research Institute, pers. comm.1998). The borehole was filled with drilling mud upon the completion of drilling. Final logging and testing of the well were completed December 5, 1969, at which time the fluid level had dropped to $79.8 \mathrm{~m}$ below land surface. The hole was then abandoned by welding a 5.1 -cm-thick steel plate to the top of the 3.1-m-diameter steel casing; a $4.9 \mathrm{~m}$ by $4.9 \mathrm{~m}$ by $0.6 \mathrm{~m}$ concrete pad was then poured on top of the steel plate (USAEC, 1974). This is the current configuration of the wellhead; there is no ready way to access the wellbore to collect new information. Therefore, all calculations are made from mud pit samples and from literature-reported values.

No lithologic data can be found for well UC-4; however, detailed lithologic descriptions are available for exploration well UCe-17, located approximately $100 \mathrm{~m}$ west of UC-4 (Hoover, 1968). Due to the close proximity of UCe-17, it is assumed that the lithology and formation tops would be very similar to UC-4. The upper $625 \mathrm{~m}$ are alluvium, composed of caliche-cemented silt to cobble sized particles of volcanic detritus. The lithology from $625 \mathrm{~m}$ to $1676 \mathrm{~m}$ (total depth) is composed of four volcanic tuff units (Orange Lichen tuff, Butte tuff, Needles tuff, and Biotite tuff). The volcanic units have varying mineralogical compositions and are from low to moderate to densely welded. 


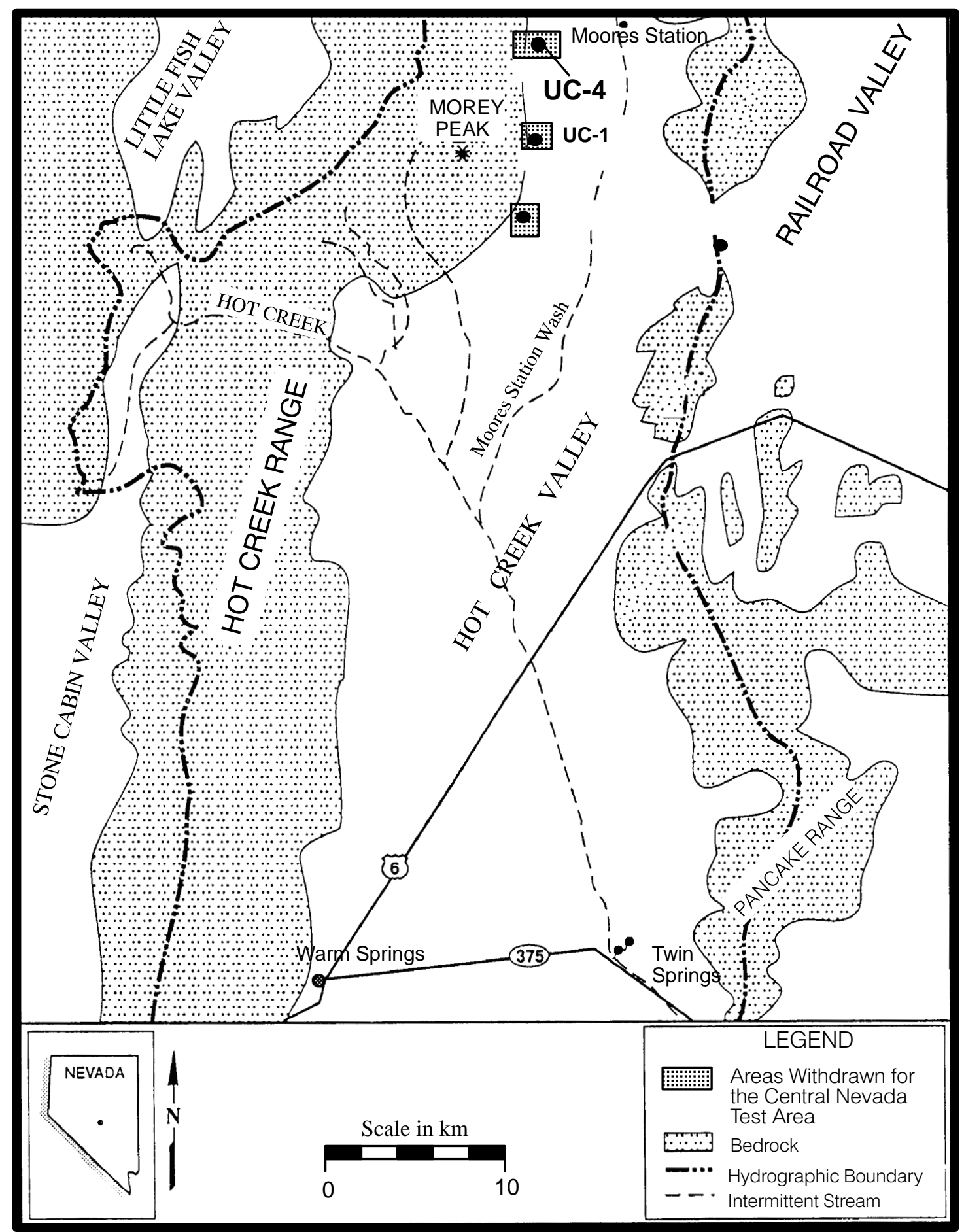

Figure 1. Location of well UC-4 at the Central Nevada Test Area in Hot Creek Valley, Nevada. 

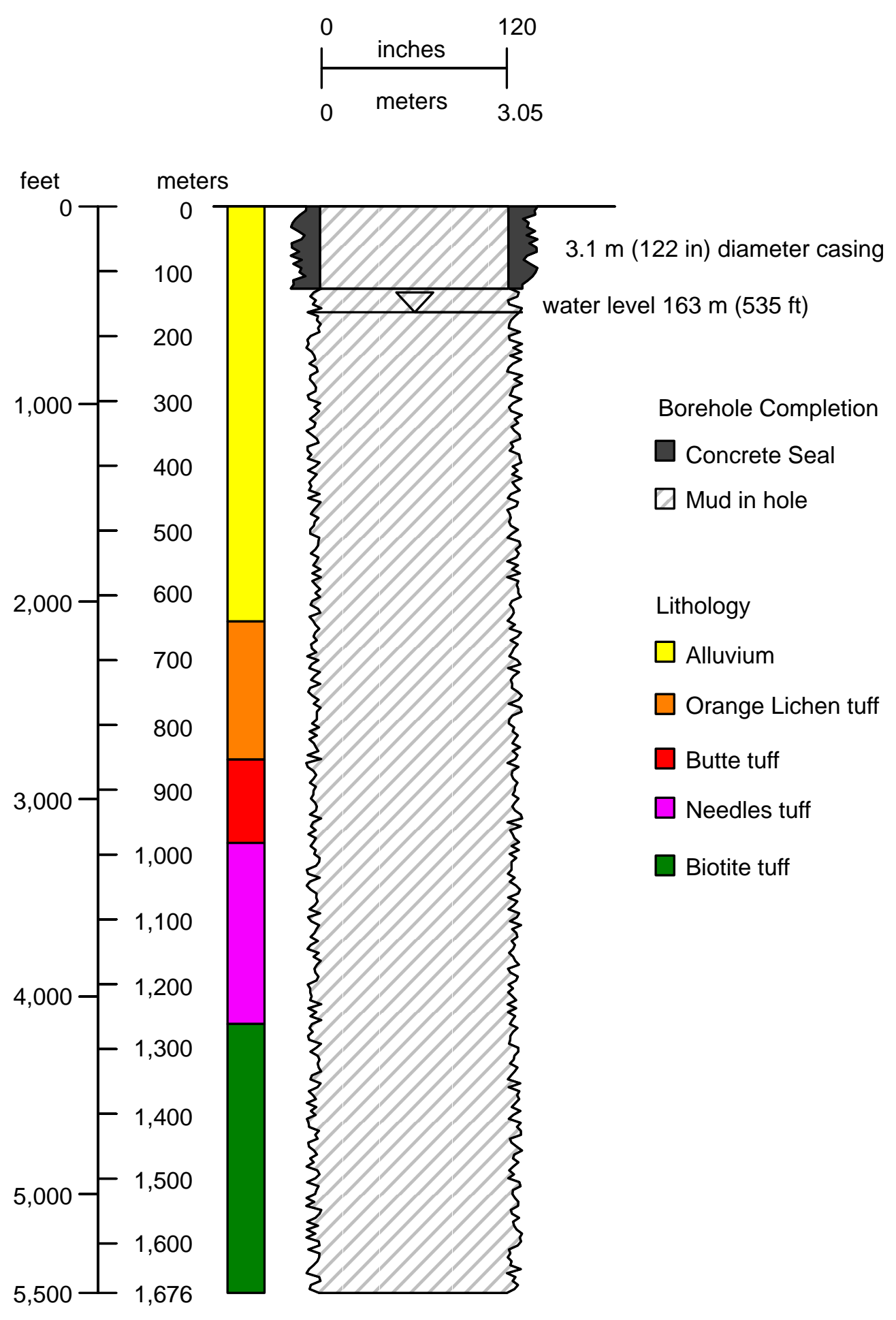

Figure 2. Generalized well schematic and lithologic log for well UC-4. 
Groundwater flow near well UC-4 is dominated by downward vertical flow, with a vertical gradient of approximately 0.1 (K. Pohlmann, Desert Research Institute, per. comm., 1998). However, the horizontal gradient is of greatest concern for this analysis of hydrocarbon transport. No wells are available in the immediate vicinity of UC-4 from which water level measurements can be made. Therefore, estimates of groundwater flow direction and gradient were made from previously measured water levels between well UCe-17 and current levels at HTH-1 near UC-1, approximately $5.7 \mathrm{~km}$ south of the UC-4 site. The horizontal gradient between UC-4 and HTH-1 was 0.02 .

Transport of TPH was presumed to be most likely at the water table in the alluvial aquifer. Values of hydraulic conductivity and porosity in the alluvial aquifer were available from UCe and HTH wells in the area, though no hydraulic conductivity values were available from well UC-4, and only values from the volcanics were available from UCe-17. The hydraulic conductivity of the alluvial aquifer has a geometric mean and $\log _{10}$ standard deviation of $0.87 \mathrm{~m} / \mathrm{yr}$ and 0.091 , respectively. The arithmetic mean and standard deviation of the porosity is 19.3 percent and 6.31 percent, respectively (K. Pohlmann, Desert Research Institute, per. comm., 1998). For the computer model calculations, the hydraulic conductivity was assumed to be log-normally distributed and the porosity was assumed to be normally distributed.

No documentation is available on the mud used to fill well UC-4. However, the mud engineer remembered that the mud was composed of bentonite and chrome lignosulfonate additives (McLauren, Summit Minerals, Denver, CO (303) 572-3011, pers. comm., 1998). Drilling mud is specifically designed to stabilize the formation, hold the hole open and carry rock cuttings during drilling operations, and by its nature is not viewed as a porous medium. Therefore, no data are available on the hydraulic conductivity or porosity of drilling mud, nor are there data on the long-term effects of the drilling mud left in wells. However, it is presumed that the mud left in UC-4 has consolidated to a clay over the past 29 years since the well was completed. Therefore, rather than performing laboratory tests on drilling mud samples, literature-reported values for clays were used to estimate the hydraulic properties of the mud-filled well. The geometric mean hydraulic conductivity of the mud was chosen to be $0.002 \mathrm{~m} / \mathrm{yr}$ with a $\log _{10}$ standard deviation of $0.0317 \mathrm{~m} / \mathrm{yr}$ and the arithmetic mean porosity of the mud was 55 percent with a standard deviation of 58.5 percent (Freeze and Cherry, 1979). For the computer model calculations the distributions were assumed to be the same as for the alluvium; the hydraulic conductivity was assumed to be log-normally distributed and the porosity was assumed to be normally distributed.

\section{ANALYTICAL SOLUTION FOR FLOW NEAR A WELL OF LOW HYDRAULIC CONDUCTIVITY}

Groundwater flow near a well is distorted due to the change in hydraulic conductivity from the aquifer to the borehole. In most cases the hydraulic conductivity of the well is greater than that of the surrounding medium, thereby deforming the flow lines toward the well. In the case of a well filled with mud, the flow lines of equal potential are distorted away from the well (Figure 3). Wheatcraft and Winterberg (1985) determined the stream functions and potential functions for this situation, which can be used to calculate the solute arrival time downgradient of the well. Given the 


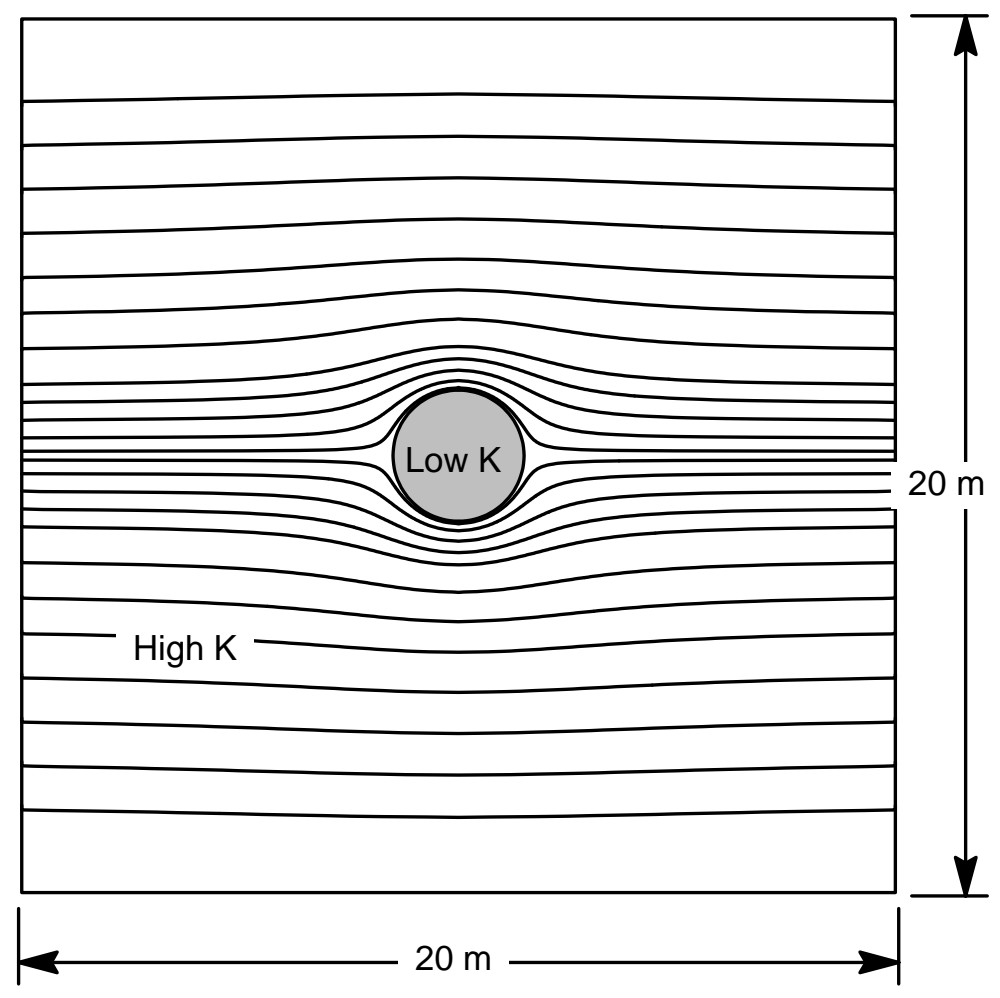

Figure 3. Flow lines of equal potential within $10 \mathrm{~m}$ of well UC-4 (developed from Eq. 3).

geometry shown in Figure 4, we can define the following parameters (with the well represented by a cylinder):

A well of a known radius, hydraulic conductivity and porosity is placed in a flow field of known hydraulic gradient, hydraulic conductivity, and porosity. Wheatcraft and Winterberg (1985) determined the velocity potential functions:

outside cylinder:

$$
\phi_{1}=x\left[U+\frac{U^{\prime} a^{2}}{x^{2}+y^{2}}\right]
$$

inside cylinder:

$$
\phi_{2}=\mathrm{U}^{\prime \prime} \mathrm{x}
$$

$$
\text { where: } \quad \begin{aligned}
\mathrm{U}^{\prime} & =\left\{\frac{1-\mathrm{k}_{\mathrm{R}}}{1+\mathrm{k}_{\mathrm{R}}}\right\} \\
\mathrm{U}^{\prime \prime} & =\frac{2 \mathrm{Uk}_{\mathrm{R}}}{1+\mathrm{k}_{\mathrm{R}}}
\end{aligned}
$$

$\mathrm{x}$ and $\mathrm{y}$ are spatial coordinates 


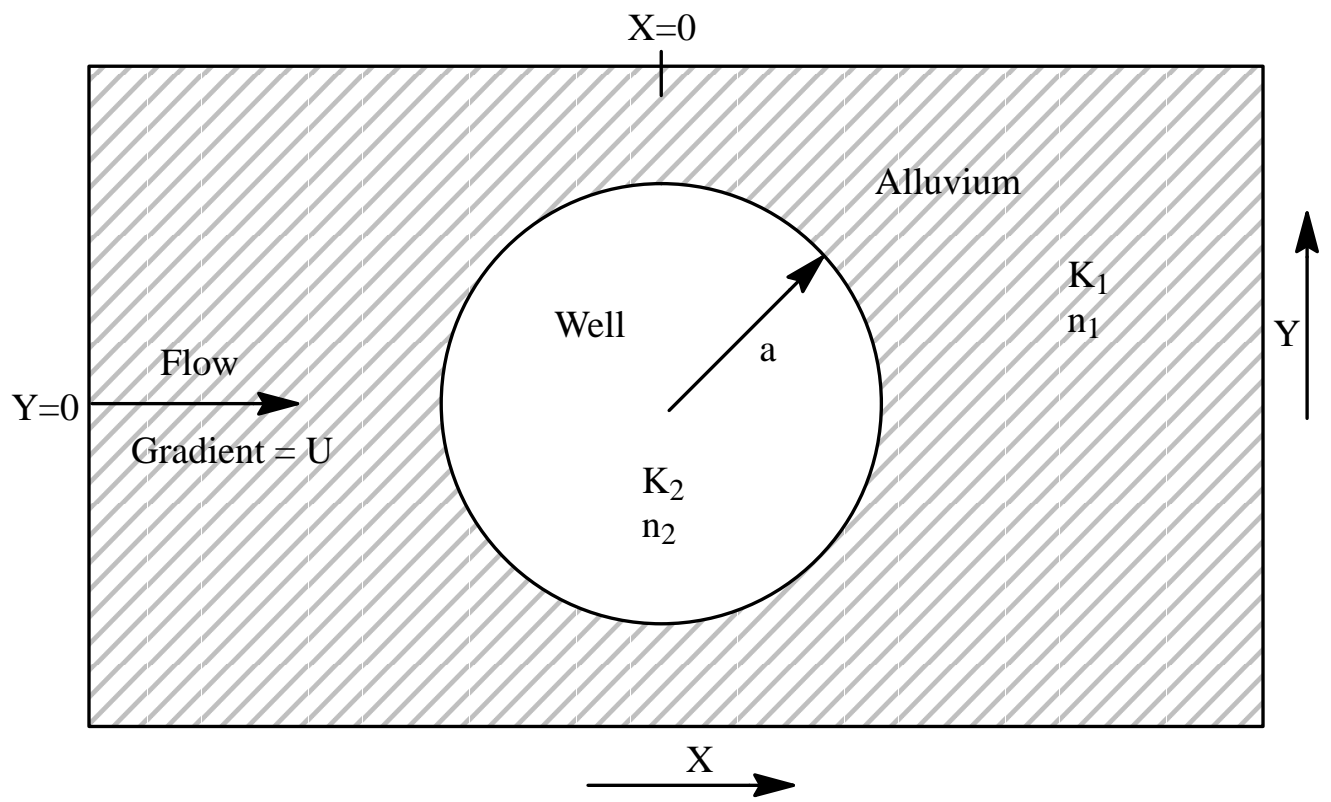

Figure 4. Geometry of analytic solution.

where: $\mathrm{a}=$ radius of cylinder (well)

$\mathrm{k}_{1}=$ hydraulic conductivity outside cylinder

$\mathrm{k}_{2}=$ hydraulic conductivity inside cylinder

$\mathrm{n}_{1}=$ effective porosity outside cylinder

$\mathrm{n}_{2}=$ effective porosity inside cylinder

$\mathrm{k}_{\mathrm{R}}=\mathrm{k}_{2} / \mathrm{k}_{1}$

$\mathrm{U}=$ uniform hydraulic gradient

Wheatcraft and Winterberg (1985) determined the stream functions:

outside cylinder:

$$
\psi_{1}=\mathrm{y}\left[\mathrm{U}-\frac{\mathrm{U}^{\prime} \mathrm{a}^{2}}{\mathrm{x}^{2}+\mathrm{y}^{2}}\right]
$$

inside cylinder:

$$
\psi_{2}=\mathrm{U}^{\prime \prime} \mathrm{y}
$$

The velocity outside of the cylinder is calculated as:

$$
\begin{gathered}
\mathrm{V}_{\mathrm{x}_{1}}=-\frac{\mathrm{k}_{1}}{\mathrm{n}_{1}} \frac{\partial \phi_{1}}{\partial \mathrm{x}}=\frac{\partial \mathrm{x}}{\partial \mathrm{t}}=-\frac{\mathrm{k}_{1}}{\mathrm{n}_{1}}\left[\mathrm{U}+\frac{\mathrm{U}^{\prime} \mathrm{a}^{2}\left(\mathrm{y}^{2}-\mathrm{x}^{2}\right)}{\mathrm{x}^{2}+\mathrm{y}^{2^{2}}}\right] \\
\mathrm{V}_{\mathrm{y}_{1}}=-\frac{\mathrm{k}_{1}}{\mathrm{n}_{1}} \frac{\partial \phi_{1}}{\partial \mathrm{y}}=\frac{\partial \mathrm{y}}{\partial \mathrm{t}}=\frac{2 \mathrm{k}_{1} \mathrm{U}^{\prime} \mathrm{a}^{2} \mathrm{xy}}{\mathrm{n}_{1}\left(\mathrm{x}^{2}+\mathrm{y}^{2}\right)^{2}}
\end{gathered}
$$

Likewise, the velocity inside the cylinder is: 


$$
\mathrm{V}_{\mathrm{x}_{2}}=-\frac{\mathrm{k}_{2}}{\mathrm{n}_{2}} \frac{\partial \phi_{2}}{\partial \mathrm{x}}=\frac{\mathrm{dx}}{\mathrm{dt}}=\mathrm{U}^{\prime \prime}
$$

Owing to $\frac{\partial \phi_{2}}{\partial \mathrm{y}}=0$, we know: $\mathrm{V}_{\mathrm{y}_{2}}=0$

The mass breakthrough at a downgradient control plane is calculated for numerous evenly distributed initial particle locations in the upper semi-circle; the lower semi-circle has an identical solution to the upper semi-circle. The travel time calculation is developed by first choosing increments of $\theta$ (see Figure 5). The $\mathrm{x}_{1}$ and $\mathrm{y}_{1}$ locations are calculated as:

$$
\begin{aligned}
& \mathrm{x}_{1}=\mathrm{a} \cos (\theta) \\
& \mathrm{y}_{1}=\mathrm{a} \sin (\theta)
\end{aligned}
$$

The $\mathrm{x}_{2}$ coordinate is the $\mathrm{x}$ coordinate at the downgradient control plane, while $\mathrm{y}_{2}$ can be determined via inversion of Equation (3). The travel time from $\left(\mathrm{x}_{1}, \mathrm{y}_{1}\right)$ to $\left(\mathrm{x}_{2}, \mathrm{y}_{2}\right)$ is determined by numerical integration of Equation (6) as:

$$
\mathrm{t}_{1}=\int_{\mathrm{y}_{2}}^{\mathrm{y}_{1}} \frac{\mathrm{n}_{1}\left(\mathrm{x}^{2}+\mathrm{y}^{2}\right)^{2}}{2 \mathrm{k}_{1} \mathrm{U}^{\prime} \mathrm{a}^{2} \mathrm{xy}} \mathrm{dy}
$$

where $\mathrm{x}$ is determined from Equation (3) as:

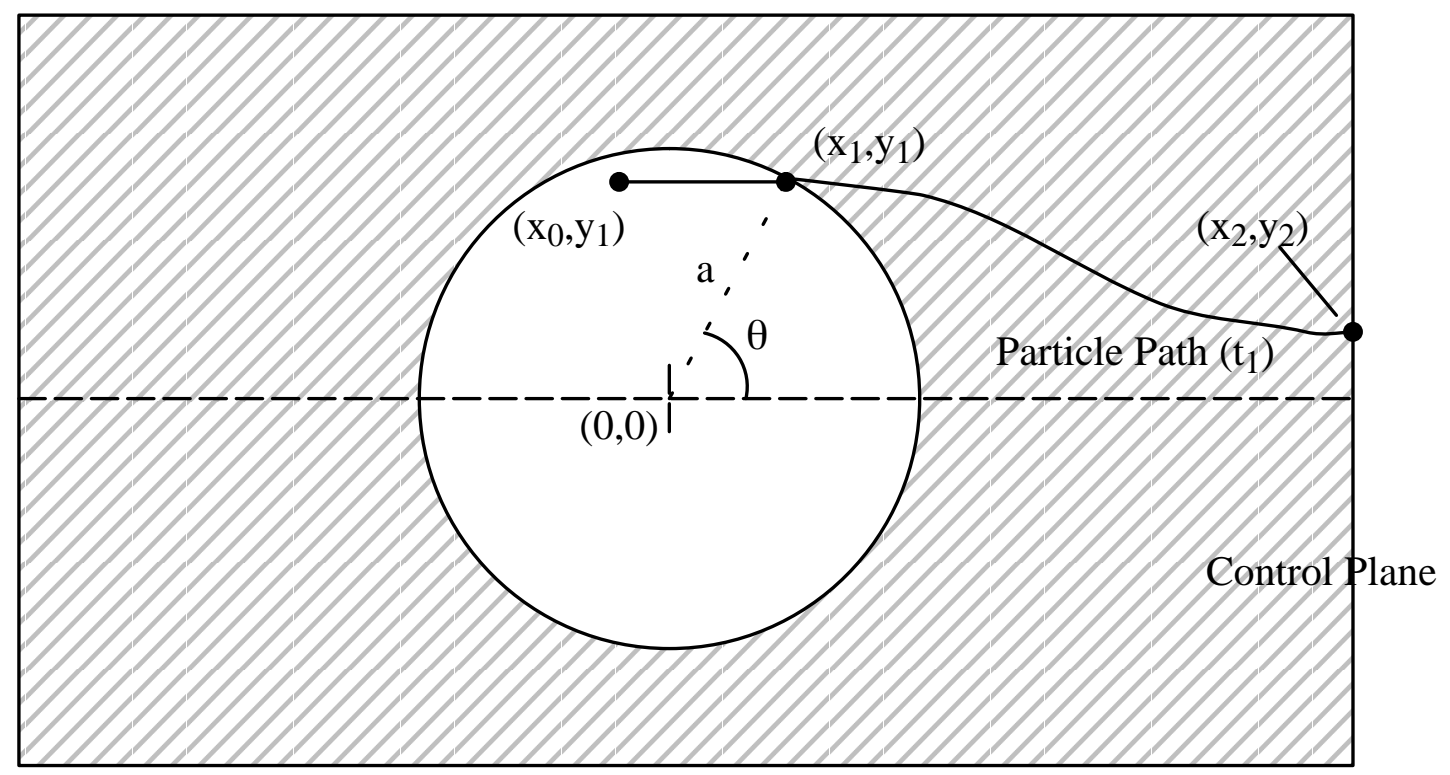

Figure 5. Diagram of particle path. 


$$
x=\left[\frac{U^{\prime} a^{2} y}{U y-\psi_{1}}-y^{2}\right]^{1 / 2}
$$

The travel time $\left(\mathrm{t}_{2}\right)$ to $\left(\mathrm{x}_{1}, \mathrm{y}_{1}\right)$, at the exterior edge of the cylinder, from any lateral point in the interior of the cylinder $\left(\mathrm{x}_{0}, \mathrm{y}_{1}\right)$ is

$$
\mathrm{t}_{2}=\frac{\left(\mathrm{x}_{1}-\mathrm{x}_{0}\right)}{\mathrm{V}_{\mathrm{x}_{2}}}
$$

where $\mathrm{V}_{\mathrm{x}_{\mathrm{z}}}=\mathrm{U}^{\prime \prime}$. Therefore, the total travel time $\left(\mathrm{t}_{\mathrm{t}}\right)$ from $\left(\mathrm{x}_{0}, \mathrm{y}_{1}\right)$ to $\left(\mathrm{x}_{2}, \mathrm{y}_{2}\right)$ is:

$$
\mathrm{t}_{\mathrm{t}}=\mathrm{t}_{1}+\mathrm{t}_{2}
$$

\section{HYDROCARBON RELEASE FUNCTION}

During the surface characterization of the CNTA, samples were collected from abandoned mud pits and yielded elevated levels of TPH (DOE, 1997). The highest concentrations were found in the central mud pit near the UC-1 site. The TPH consists of diesel fuel, motor oil, and crude oil, and is suspected to be from an equipment wash-rack that was adjacent to the mud pit or from mud additives, although no written documentation is available to substantiate the source. There were five mud pits used for the drilling operations at UC-4. The TPH concentrations from the UC-4 mud pits were less than those from the central mud pit and it is believed that no mud from the central mud pit was used at UC-4; however, it is possible that the same practices used at UC-1 may have been used at UC-4. Also, as previously mentioned, it was a common practice to use diesel fuel during fishing operations, such as the 30-day operation during the drilling of UC-4. Since it was not possible to retrieve in situ samples from the UC-4 borehole, samples were collected from the central mud pit for laboratory analyses.

Sampling locations were selected by targeting the highest concentrations of TPH found during the mud-pit characterization by IT Corporation (IT) (DOE, 1997). Samples were collected from two depths in four shallow hand-dug pits. Samples were stored in $1 \mathrm{~L}$ amber glass jars at $4{ }^{\circ} \mathrm{C}$ until they were analyzed. Portions of two of the samples were analyzed for physical properties. It can be seen from Table 1 that both samples have extremely similar physical characteristics. For example, the average density and average pore diameters of both samples are almost identical. In addition, both samples have similar particle size distributions and porosities. This similarity in the physical parameters of the two samples would suggest that all samples tend to have somewhat consistent and uniform physical properties. These properties are also consistent with what was known about the drilling mud. For example, it is known that the drilling mud was composed of bentonite clay. Bentonite clay is an altered volcanic ash with montmorillonite as the dominant clay mineral (Klein and Hurlbut, 1993). In general, clay minerals have high porosities and very small particle sizes, and these physical properties are manifested in both samples. In addition, montmorillonite clay has an average density of $2.5 \mathrm{~g} / \mathrm{cm}$, and it can be seen from Table 1 that both field samples have almost 
identical values. Bentonite clay also has the unusual property of expanding several times its original volume when placed in water. This property explains why bentonite clays are used as a drilling mud because the clay-water mixture gives the fluid a viscosity several times that of water. It is also used for stopping leakage in soil and rocks (Klein and Hurlbut, 1993).

Table 1. A Summary of the Physical Characteristics of the Bentonite Drilling Mud Samples from the Central Mud Pit.

\begin{tabular}{lcc}
\hline & Sample $2-2$ & Sample 4-1 \\
\hline Average Density & $2.50 \mathrm{~g} / \mathrm{cm}^{3}$ & $2.49 \mathrm{~g} / \mathrm{cm}^{3}$ \\
Average Pore Diameter & $162.6 \mu \mathrm{m}$ & $162.6 \mu \mathrm{m}$ \\
Porosity & $16.99 \%$ & $23.37 \%$ \\
BET-Surface Area & $13.2 \mathrm{~m}^{2} / \mathrm{g}$ & $9.7 \mathrm{~m}^{2} / \mathrm{g}$ \\
Mean Mass Distribution & $2.3 \mu \mathrm{m}$ & $5.3 \mu \mathrm{m}$ \\
Mode Mass Distribution & $2.2 \mu \mathrm{m}$ & $2.5 \mu \mathrm{m}$ \\
Median Mass Distribution & $0.4 \mu \mathrm{m}$ & $0.6 \mu \mathrm{m}$ \\
\hline
\end{tabular}

To calculate dissolution constants of the TPH from the drilling mud, it was necessary to perform partitioning experiments as a function of time. The partitioning experiments provided data relating the equilibrium concentration of TPH in the aqueous phase to the sorbed concentration of $\mathrm{TPH}$ in the solid phase. To calculate the partitioning parameters, the drilling mud from a specific location was sub-sampled and divided into approximately 25 additional samples. These smaller samples (approximately $2.0 \mathrm{~g}$ each) were then placed into $40-\mathrm{mL}$ amber glass volatile organic analysis (VOA) vials with Teflon-lined caps. Forty milliliters of synthetic groundwater was then added to the VOA vials to simulate contact with the groundwater at the CNTA. The synthetic groundwater used was made to be representative of the chemical composition of the groundwater from well HTH-1 from the Faultless site at a depth of $741 \mathrm{~m}$. The 40-mL VOA vials containing the drilling mud and synthetic groundwater were then agitated on a Labquake Shaker at room temperature for increasing amounts of time.

After any one sample was sacrificed, it was then centrifuged at 3,000 rpm for 45 minutes to achieve a solid-solution separation. The aqueous phase was then removed from the solid phase and filtered using a vacuum flask and 45-micron glass-fiber filter to remove any remaining solid particles. The remaining water was then transferred into a $100-\mathrm{mL}$ glass volumetric flask and filled to volume. The TPH water mixture was extracted by the addition of $3 \mathrm{~mL}$ of high pressure liquid chromatography-grade (HPLC-grade) hexane. After the aqueous phase had been removed from the 40-mL VOA vials, $6 \mathrm{~mL}$ of acetone were added to the remaining solid and the resulting mixture was then agitated for another 24 hours. The addition of $6 \mathrm{~mL}$ of acetone to the solid phase was intended to completely remove any remaining TPH from the solid phase. After the mixture was shaken for 24 hours, the entire contents were transferred to a $100-\mathrm{mL}$ glass volumetric flask and filled to volume. The solid-water-acetone mixture was then also extracted with $3 \mathrm{~mL}$ of HPLC-grade hexane.

Both the equilibrium and sorbed samples were analyzed by gas chromatography (GC) to determine their TPH concentrations. The analysis method was based on U.S. Environmental 
Protection Agency (EPA) method 8015 (U.S. EPA, 1986). The TPH-hexane solutions were injected straight into the GC. The analysis was carried out by injecting $2 \mathrm{~mL}$ of extract using the solvent flushing technique into a GC (Hewlett Packard Series II Gas Chromatograph) equipped with a flame ionization detector. The column was a 30-m long, $0.54 \mathrm{~cm}$ I.D., capillary column with a film thickness of $1.2 \mathrm{~mm}$ (Alltech Associates, Catalog No. 955130, phase-AT-5). The oven was set to an initial temperature of $50^{\circ} \mathrm{C}$ and held for 1 minute. The temperature was then ramped to $260{ }^{\circ} \mathrm{C}$ at the rate of $15^{\circ} \mathrm{C} / \mathrm{min}$ and was held at the final temperature for 10 minutes. Inlet and detector were maintained at $270^{\circ} \mathrm{C}$. An equilibration time of 1 minute between runs was allowed after the oven temperature reached $50^{\circ} \mathrm{C}$. The different gases used in the $\mathrm{GC}$ and their flow rates are as follows: Hydrogen Flame Ionization Detector-30 ml/min; Air Flame Ionization Detector- 200 ml/min; and Helium (Carrier)-2 $\mathrm{ml} / \mathrm{min}$.

The chromatograms for each sample were obtained and integrated using Hewlett Packard Chemstation Series II software. A typical example of the obtained chromatograms can be seen in Figure 6. The figure shows the GC chromatogram obtained from the equilibrium concentration of TPH after 35 days of equilibration for sample 1-1b. A standard containing straight-chain alkanes, C-9 through C-25 (Alltech Associates, Hydrocarbon kit, Cat. No. 18484) was used to calibrate the GC. A calibration curve was established for the TPH concentration in parts per million (ppm by volume) against the area under the TPH chromatogram by analyzing the standard at different lab concentrations $(1,000,100,50$, and $10 \mathrm{ppm})$. The calibration curve was then used to calculate the unknown TPH concentrations present in both the aqueous and solid phase samples.

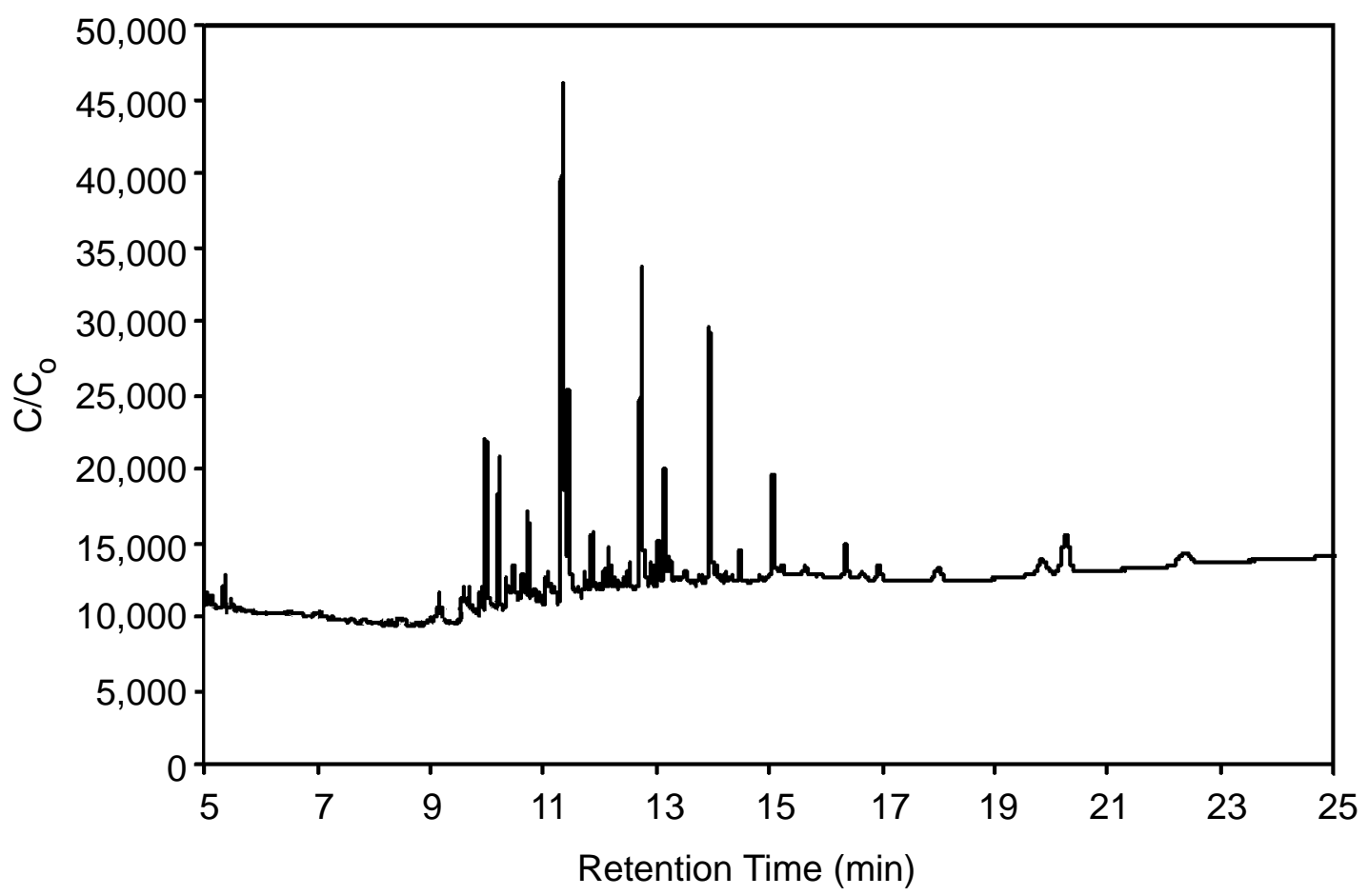

Figure 6. GC/FID chromatogram of the 35-day equilibrium TPH concentration of sample 1-1b. 
The partitioning parameters relating the concentration of TPH in the aqueous phase to the concentration of TPH in the solid phase were calculated by analyzing each sample for its TPH concentration and applying the results to the following equation:

$$
\mathrm{K}_{\mathrm{d}}=\frac{\mathrm{S}}{\mathrm{C}}
$$

where $\mathrm{K}_{\mathrm{d}}$ is the distribution coefficient $\left(\mathrm{m}^{3} / \mathrm{g}\right)$; $\mathrm{S}$ is the sorbed concentration in grams of TPH sorbed per gram of solid $(\mathrm{g} / \mathrm{g})$; and $\mathrm{C}$ is the equilibrium concentration of TPH in the aqueous phase $\left(\mathrm{g} / \mathrm{m}^{3}\right)$.

The rate constants describing the dissolution of TPH from the bentonite drilling mud were also calculated using the equilibrium concentration of TPH in the aqueous phase and the original concentration of TPH in both the aqueous and solid phases. The dissolution constants were calculated by fitting the data to the following first-order equation:

$$
\frac{\mathrm{dC}_{\mathrm{n}}}{\mathrm{dt}}=-\mathrm{kC}
$$

where $\mathrm{C}_{\mathrm{n}}$ is the normalized ratio of the equilibrium concentration of TPH to the original TPH concentration in both the solid and liquid phases $\left(\mathrm{C} / \mathrm{C}_{\mathrm{o}}\right)$; $\mathrm{k}$ is the first-order rate constant $\left(\mathrm{day}^{-1}\right)$; and $\mathrm{C}$ is the aqueous concentration of TPH. Integration of the previous equation yields the following linear equation:

$$
\ln \left(\frac{\mathrm{C}}{\mathrm{C}_{\mathrm{o}}}\right)=-\mathrm{kt}+\text { CONSTANT }
$$

where the first-order rate constant describing the dissolution of TPH from the bentonite drilling mud can then be calculated by plotting the $\ln \left(\mathrm{C} / \mathrm{C}_{\mathrm{o}}\right)$ values versus time and then doing a best-fit linear regression of the data to determine the slope of the line.

\section{Laboratory Results and Discussion}

The time-dependent partitioning experiments were performed on five of the mud-pit samples from the CNTA. The samples investigated were 1-1, 1-1b, 2-2, 4-1, and 4-2. These samples were selected for study because preliminary experiments revealed that these particular mud samples contained significant quantities of TPH. In general, the time-dependent partitioning experiments revealed that the distribution coefficients for the different samples, which relate the sorbed concentration to the equilibrium concentration, decreased as time increased. For example, this type of behavior can be seen in Figure 6, which shows the distribution coefficients as a function of time for sample 1-1b. It can be seen in the figure that the distribution coefficients decrease from a maximum value of approximately $1.20 \times 10^{-4} \mathrm{~m}^{3} / \mathrm{g}$ to a minimum value of $1.26 \times 10^{-5} \mathrm{~m}^{3} / \mathrm{g}$ as time increases. This behavior indicates that as time increases the aqueous concentration of TPH increases for a given sample.

The distribution coefficients calculated as a function of time for each sample can be seen in the Appendix. The distribution coefficients for any one sample vary by at most two orders of 
magnitude and usually by only one order of magnitude. It can also be seen from the data in the Appendix that the distribution coefficients between the various samples at similar days are also similar. This is somewhat expected given the similarity in the physicochemical characteristics of the mud-pit samples. The raw data from the chromatograms revealed, however, that the actual TPH concentrations for the samples were extremely variable. In fact, the TPH concentrations for an individual sample that had been sub-sampled were highly variable, indicating an extreme heterogeneity in the TPH concentration in the mud pit. This variability in the TPH concentration was also reported by IT in their preliminary characterization of the central mud pit (DOE, 1997).

The first-order rate constants describing the dissolution of TPH from the bentonite drilling mud can be seen in Table 2. The data that were used to calculate the rate constants for the individual samples can also be seen in the Appendix. The rate constants were calculated by a linear regression of the $\ln \left(\mathrm{C} / \mathrm{C}_{\mathrm{o}}\right)$ versus time data. It can be seen from Table 2 that the rate constants vary from a maximum value of 0.1102 per day to a minimum value of 0.0216 per day. Three of the five different samples have almost identical rate constants. This similarity in the first-order rate constants suggests that the dissolution of TPH from the bentonite drilling mud is fairly consistent even though the overall TPH concentration is extremely variable within the mud pit. This can be attributed to the similar physical characteristics of the bentonite drilling mud.

Table 2. First-Order Rate Constants for the Dissolution of TPH from Bentonite Drilling Mud.

\begin{tabular}{cccc}
\hline Sample ID & First-Order Rate Constant (k) day ${ }^{-1}$ & Intercept & $\mathrm{R}^{2}$ \\
\hline $1-1$ & 0.0509 & -1.1381 & 0.64 \\
$1-1 \mathrm{~b}$ & 0.0216 & -1.2079 & 0.68 \\
$2-1$ & 0.0223 & -1.2027 & 0.52 \\
$4-1$ & 0.0284 & -1.0485 & 0.38 \\
$4-2$ & 0.1102 & -1.6862 & 0.28 \\
\hline
\end{tabular}

\section{COMPUTER MODEL DESIGN AND RESULTS}

A computer model was developed to solve the analytic solution previously described (see Equations 12-15). One-hundred Monte Carlo realizations were run from randomly chosen values of hydraulic conductivity and porosity from the alluvium and drilling-mud distributions. One-thousand particles were uniformly distributed within the mud-filled well, and the travel times for the particle to reach a control plane were monitored. An exponential release function was incorporated in the model to retard the travel times based on the TPH experimental results. Results from the model simulation are shown in Figure 7; the center breakthrough line is the mean, bounded by lines of \pm two standard deviations. The first particles reached a plane $10 \mathrm{~m}$ from the center of the well in 262 years, the median breakthrough took 12,216 years to reach $10 \mathrm{~m}$, and the final particles traveled $10 \mathrm{~m}$ in 33,401 years.

Flow lines are not affected greatly by the low hydraulic conductivity well at a distance of $10 \mathrm{~m}$ (see Figure 3); therefore, Darcian flow will control the transport of TPH from the $10 \mathrm{~m}$ control plane 


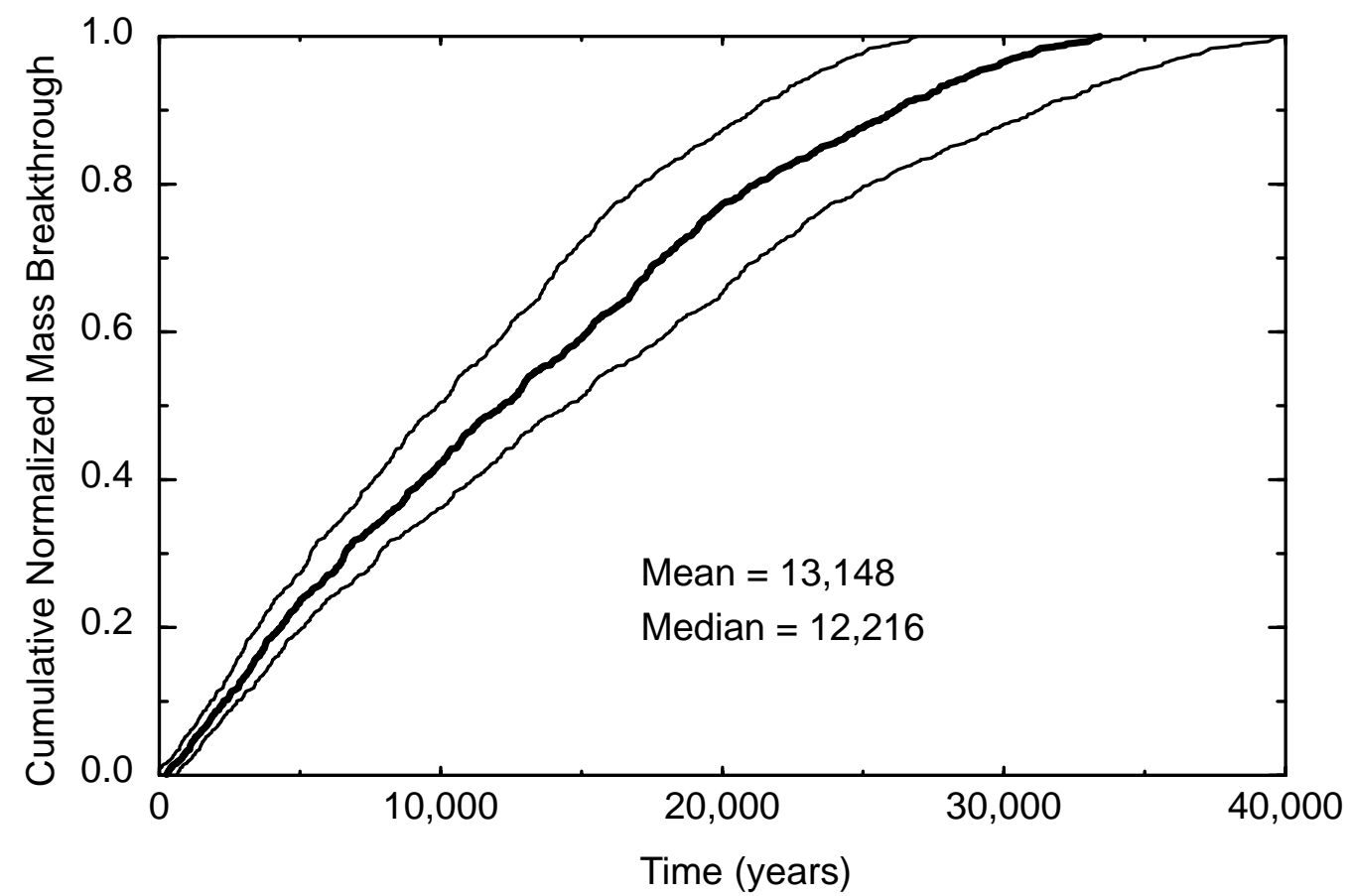

Figure 7. Cumulative normalized mass breakthrough of total petroleum hydrocarbon $10 \mathrm{~m}$ from the center of well UC-4 versus time. (Center breakthrough line is the mean, bounded by breakthrough lines of \pm 2 standard deviations.)

to the U.S. Department of Energy (DOE) land withdrawal boundary. Although the groundwater flow direction is not well defined in this area, in a worst-case scenario, the shortest flowpath would be essentially due south (equalling approximately $800 \mathrm{~m}$ ). It would take an additional 45,455 years for the contaminant to travel from the 10 -m plane to the DOE land boundary; however, the travel time would be much longer if advection, dispersion and sorption were taken into account. TPH travel times were affected primarily by the hydraulic conductivity and porosity of the drilling mud, then by the hydraulic properties and gradient in the alluvium, followed by the TPH release.

\section{CONCLUSIONS}

An analytical mathematic solution was developed to compute the flow velocities near the drilling-mud-filled borehole, UC-4. Contaminant transport was retarded based on the TPH release function experiments performed as part of this study. To travel $10 \mathrm{~m}$, the median contaminant breakthrough occurred in about 12,000 years; the initial breakthrough took about 260 years and the final breakthrough took about 33,400 years. It would take tens of thousands of years, at a minimum, for the contaminant to travel beyond the DOE land boundary $(800 \mathrm{~m})$. The forces of advection, dispersion, sorption and biodegradation were not included as part of this study, but it is believed that these forces would significantly increase the travel times. 


\section{REFERENCES}

Fenix and Sisson, 1968. UC-4 Hole History.

Freeze, R.A. and J.A. Cherry, 1979. Groundwater. Prentice Hall Pub.

Hoover, D.L., 1968. Lithology Log of Drill Hole UCe-17, and General Geology of the UCe-17 Area, Hot Creek Valley, Nevada. U.S. Geological Survey, Technical Letter: Central Nevada-13, 14 pp.

Klein, C. and C.S. Hurlbut, 1993. Manual of Mineralogy. New York, NY. John Wiley \& Sons, 681 pp.

U.S. Atomic Energy Commission, 1974. Summary Report: Central Nevada Test Area Demobilization and Restoration Activities. Nevada Operations Office, NVO-152. Las Vegas, NV.

U.S. Department of Energy, 1997. Central Nevada Test Area, CAU No. 417, Surface Investigation Characterization Report. Nevada Operations Office, DOE/NV-UC-700. Las Vegas, NV.

U.S. Department of Energy, 1998. Corrective Action Investigation Plan for the Central Nevada Test Area Subsurface Sites (Corrective Action Unit No. 443), Nevada Operations Office, DOE/NV--483. Las Vegas, NV.

U.S. Environmental Protection Agency, 1986. Test Methods for Evaluating Solid Waste, Volume 1B: Laboratory Manual for Physical/Chemical Methods. SW-846. Washington, D.C.

Wheatcraft, S.W. and F. Winterberg, 1985. Steady-state flow passing through a cylinder of permeability different from the surrounding medium. Water Resources Research, 21(12):1923-1929. 


\section{APPENDIX}

TPH EXPERIMENTAL RESULTS 
Table A 1. Distribution Coefficients and ln (C/Co) Values for Sample 1-1.

\begin{tabular}{ccc}
\hline Days & $\mathrm{Kd}\left(\mathrm{m}^{3} / \mathrm{g}\right)$ & $\ln \left(\mathrm{C} / \mathrm{C}_{\mathrm{o}}\right)$ \\
\hline 1 & $1.20 \times 10^{-4}$ & -1.32 \\
3 & $8.98 \times 10^{-5}$ & -0.687 \\
6 & $9.66 \times 10^{-5}$ & -1.12 \\
8 & $7.17 \times 10^{-5}$ & -0.409 \\
10 & $7.41 \times 10^{-5}$ & -0.504 \\
12 & $2.35 \times 10^{-7}$ & 5.23 \\
28 & $2.66 \times 10^{-6}$ & 2.79 \\
\hline
\end{tabular}

Table A 2. Distribution Coefficients and In (C/Co) Values for Sample 1-1b.

\begin{tabular}{ccc}
\hline Days & $\mathrm{Kd}\left(\mathrm{m}^{3} / \mathrm{g}\right)$ & $\ln \left(\mathrm{C} / \mathrm{C}_{\mathrm{o}}\right)$ \\
\hline 1 & $1.20 \times 10^{-4}$ & -1.32 \\
3 & $8.97 \times 10^{-5}$ & -1.09 \\
5 & $7.23 \times 10^{-5}$ & -0.997 \\
8 & $7.17 \times 10^{-5}$ & -0.919 \\
10 & $7.41 \times 10^{-5}$ & -0.977 \\
20 & $4.02 \times 10^{-5}$ & -0.634 \\
22 & $9.52 \times 10^{-5}$ & -1.09 \\
24 & $6.38 \times 10^{-5}$ & -0.786 \\
35 & $1.26 \times 10^{-5}$ & -0.252 \\
44 & $1.57 \times 10^{-5}$ & -0.280 \\
\hline
\end{tabular}

Table A 3. Distribution Coefficients and In (C/Co) Values for Sample 2-2.

\begin{tabular}{ccc}
\hline Days & $\mathrm{Kd}\left(\mathrm{m}^{3} / \mathrm{g}\right)$ & $\ln \left(\mathrm{C} / \mathrm{C}_{\mathrm{o}}\right)$ \\
\hline 1 & $8.76 \times 10^{-5}$ & -1.06 \\
3 & $1.71 \times 10^{-4}$ & -1.73 \\
8 & $2.05 \times 10^{-5}$ & -0.427 \\
33 & $5.46 \times 10^{-5}$ & -0.774 \\
35 & $1.77 \times 10^{-5}$ & -0.326 \\
37 & $2.14 \times 10^{-5}$ & -0.379 \\
40 & $1.03 \times 10^{-5}$ & -0.222 \\
\hline
\end{tabular}


Table A 4. Distribution Coefficients and $\ln (\mathrm{C} / \mathrm{Co})$ Values for Sample 4-1.

\begin{tabular}{ccc}
\hline Days & $\mathrm{Kd}\left(\mathrm{m}^{3} / \mathrm{g}\right)$ & $\ln \left(\mathrm{C} / \mathrm{C}_{\mathrm{o}}\right)$ \\
\hline 1 & $1.54 \times 10^{-4}$ & -1.51 \\
3 & $5.78 \times 10^{-5}$ & -0.840 \\
7 & $1.39 \times 10^{-5}$ & -0.265 \\
10 & $6.75 \times 10^{-5}$ & -0.863 \\
22 & $1.91 \times 10^{-5}$ & -0.400 \\
24 & $3.77 \times 10^{-5}$ & -0.511 \\
\hline
\end{tabular}

Table A 5. Distribution Coefficients and $\ln (\mathrm{C} / \mathrm{Co})$ Values for Sample 4-2.

\begin{tabular}{ccc}
\hline Days & $\mathrm{Kd}\left(\mathrm{m}^{3} / \mathrm{g}\right)$ & $\ln \left(\mathrm{C} / \mathrm{C}_{\mathrm{o}}\right)$ \\
\hline 1 & $1.113 \times 10^{-4}$ & -1.02 \\
2 & $4.81 \times 10^{-4}$ & -2.50 \\
3 & $7.47 \times 10^{-5}$ & -0.769 \\
8 & $1.53 \times 10^{-4}$ & -1.23 \\
10 & $1.82 \times 10^{-5}$ & -0.268 \\
\hline
\end{tabular}




\section{DISTRIBUTION}

Raymon D. Cox, Acting, Director

Contract Management Division

Nevada Operations Office

U.S. Department of Energy

P.O. Box 98518

Las Vegas, NV 89193-8518

Beverly Colbert

Contract Management Division

Nevada Operations Office

U.S. Department of Energy

P.O. Box 98518

Las Vegas, NV 89193-8518

Doug Duncan

Hydrology Program Manager

Environment, Safety \& Health Division

Nevada Operations Office

U.S. Department of Energy

P.O. Box 98518

Las Vegas, NV 89193-8518

Kenneth A. Hoar, Director

Environment, Safety \& Health Division

Nevada Operations Office

U.S. Department of Energy

P.O. Box 98518

Las Vegas, NV 89193-8518

Marjory Jones

Desert Research Institute

Water Resources Center

2215 Raggio Parkway

Reno, NV 89512-1095

Randy Laczniak

U.S. Geological Survey

Water Resources Division

6770 S. Paradise Rd.

Las Vegas, NV 89119
Leslie A. Monroe

Environment, Safety \& Health Division

Nevada Operations Office

U.S. Department of Energy

P.O. Box 98518

Las Vegas, NV 89193-8518

Mike Sabbe

Bechtel Nevada

P.O. Box 98521

Las Vegas, NV 89193-8521

Monica Sanchez

Environmental Restoration Division

Nevada Operations Office

U.S. Department of Energy

P.O. Box 98518

Las Vegas, NV 89193-8518

Peter Sanders

Environmental Restoration Division

Nevada Operations Office

U.S. Department of Energy

P.O. Box 98518

Las Vegas, NV 89193-8518

David Shafer

Water Resources Center

Desert Research Institute

755 E. Flamingo Road

Las Vegas, NV 89119-7363

David K. Smith

Isotopes Sciences Division

Lawrence Livermore National Laboratory

P.O. Box 808, M/S L231

Livermore, CA 94550

Doug Trudeau

U.S. Geological Survey

Water Resources Division

6770 S. Paradise Rd.

Las Vegas, NV 89119

Tim White

International Technology Corporation

P.O. Box 93838, M/S 439

Las Vegas, NV 89193-3838 
Runore C. Wycoff, Director

Environmental Restoration Division

Nevada Operations Office

U.S. Department of Energy

P.O. Box 98518

Las Vegas, NV 89193-8518

Nevada State Library and Archives

State Publications

100 North Stewart Street

Carson City, NV 89710-4285

Archives

Getchell Library

University of Nevada, Reno

Beverly Carter

MacKay School of Mines Library

University of Nevada, Reno

Document Section, Library

University of Nevada, Las Vegas

4505 Maryland Parkway

Las Vegas, NV 89154

Library

Desert Research Institute

2215 Raggio Parkway

Reno, Nevada 89512-1095
Library

IT Corporation

Bldg. B-1

P.O. Box 93838, M/S 439

Las Vegas, NV 89193-3838

ATTN: Toni Miller, M/S 439

Library

Southern Nevada Science Center

Desert Research Institute

755 E. Flamingo Road

Las Vegas, NV 89119-7363

Technical Information Resource Center

Nevada Operations Office

U.S. Department of Energy

P.O. Box 98518

Las Vegas, NV 89193-8518

Public Reading Facility

Nevada Operations Office

U.S. Department of Energy

P.O. Box 98521

Las Vegas, NV 89193-8521

Office of Scientific and Technical Information

U.S. Department of Energy

P.O. Box 62

Oak Ridge, TN 37831-9939 